\title{
Substantiation of Parameters Determining the Erosion Degree of Chernozemic Soils of the South- ern Urals
}

\author{
Igor V. Sinyavskiy \\ Federal State Budgetary Educational Institution of Higher Education \\ "South Ural State Agrarian University", \\ Insitute of Agroecology, branch of SUSAU, \\ Chelyabinsk, Russia
}

\begin{abstract}
The study and analysis of the morphological markers of chernozemic soils erosion class have determined that typical chernozem on slopes with inclination from 3 to 4 degrees of both southern and northern facing features weak to moderate outwash of humic layers; leached chernozem features weak to strong outwash. Water erosion is more prominent on slopes with southern facing. Using the results of regression analysis and data on minimal and critical content of fertilizer elements and humus in chernozemic soils of the Southern Urals, the grading scale for the erosion class of eroded soils was calculated that allows determining the erosion degree with minimum costs and decide on the necessity of activities stopping the erosion and enhancing soil fertility. The scale calculates threshold parameters that segregate groups of soils by erosion level depending on the slope facing, relief, vegetation and intensity of land use for farming; in total, three soil groups were identified in terms of erosion level: acceptable, unacceptable and critical.
\end{abstract}

Keywords - chernozemic eroded soils, erosion class, wind and water erosion, slope facing.

\section{INTRODUCTION}

Diverse soils of the Southern Urals, variety of geomorphological conditions and active implementation of intense cropping technologies without soil protection pave the way for water and wind erosion. Currently, these processes take place even on those territories, where chernozemic soil degradation did no appreciable damage to its fertility. According to the data of the Committee on Land Resources and Land Tenure of Chelyabinsk Region, the total area of erosion-hazard and eroded soils in the region amounts to $1295.09 \mathrm{~K}$ hectares, including $413.84 \mathrm{~K}$ hectares of deflation-hazard ploughland, $870.65 \mathrm{~K}$ hectares suffering from water erosion, $3.8 \mathrm{~K}$ hectares of eroded hayfields and $6.8 \mathrm{~K}$ hectares of grassland [1]. However, modern soil surveys have shown that this area is much bigger. For instance, in northern forest steppe where only Uisk-Chebarkul region was distinguished with sheet water erosion, this process manifests on ploughland with slopes from 1.5 to 4 degrees and southern facing. In southern forest steppes, erosion processes vary largely from weak manifestation to strong deflation and soil washout. For a long time, it was believed that steppe barren zones primarily demonstrate deflation, due to smooth slightly-undulating relief, predominance of strong southern and south-western winds and low forest coverage [2]. Over the recent years, it was noted that on south-facing slopes even at relatively low snow accumulation, the intense thawing leads to removal of surface soil. While the yearly change of mass and relative parameters characterizing the soil are negligible and do not trigger the conversion of chernozem territory to some erosion class according to currently existing grading. Though the main markers of water erosion are obvious. This negative effect is especially strong for soils located on territories with appreciable inclination (34 degrees) of south or south-east facing slopes [1]. Application of soil protection systems facilitated deceleration of degradation processes; however, the erosion degree of chernozemic soils of slopes in agrocoenosis (especially ploughlands) is fairly high and, assumably, grows. The issue of increasing erosion degree of chernozemic soils is still understudied, while the effective measures for fertility restoration are underdeveloped for farming on territories having erosion-hazard slopes.

\section{STATEMENT OF PROBLEM}

The research is aimed at the development of assessment parameters that allow diagnosing the erosion degree of sloped chernozemic soils of the Southern Urals. To achieve the goal, the following problems were solved: determining experimental sites with different erosion degree of chernozemic soils and slope facing; comparing physicochemical and mechanical properties of eroded soils at experimental sites and under minimal human impact, determining the biomass of plants and conditions under which the erosion processes have minimum detrimental impact on the fertility of eroded slope soils; elaborating threshold indicators which can be used to distinguish soil groups in terms of erosion degree depending on the slope facing, relief, vegetation and farming intensity.

\section{THEORY}

The soil erosion mapping of the Southern Urals was performed in the end of the previous century. The main principles of territory partition into soil erosion regions were natural conditions, peculiarities in land usage and character of erosion processes [3].

The selection of experimental sites considered soil and climatic conditions of erosion initiation, farming intensity, presence on the territory of virgin analogues of chernozemic soils, possible abundance of agronomic crops, facing and inclination of slopes.

Soil cross sections, heeling-ins and sites for selection of monolith samples were located in three soil erosion regions, each being referenced to the terrain and having its coordinates determined. The territory of the experimental sites allowed 
determining the linear routes embracing the slopes with different facing at relatively short distances.

To receive the data characterizing the topsoil of the territory under study and select a location for experimental sites that enable gathering parameters determining the territory erosion degree, we have made soil cross sections in top, middle and bottom parts of the slopes with northern and southern facing. In addition, heeling-ins were made to obtain additional samples. Field studies were carried out as per Russian standard OST 56-81-84. In total, 12 cross sections were made and described; 32 soil heeling-ins were performed as well. To get data on the properties of ploughing horizon of leached chernozems, we have sampled soil in different locations along the slope and for different facing.

The samples were prepared for chemical analysis as per Russian standard GOST 17.4.4.02-84 and analyzed in a special agrochemical laboratory for the following properties using the techniques noted below.

Determination of granulometric composition as per GOST 12535-2014, soil bulk density as per GOST 5180-84, soil humidity as per GOST $28268-89$, salt extract $\mathrm{pH}$ as per CINAO GOST 26483-85, modified humus determination in soils by Tyurin method with photocolorimetric finishing as per industrial standard OST 46 47-76, alkali-hydrolizable nitrogen as per Cornfield method (modified by CINAO), total phosphorus content as per GOST 26261-84, total nitrogen as per GOST 26107-84, active forms of phosphorus and potassium by Chirikov method (modified by CINAO) as per GOST 26204-91 [4].

The vegetation biomass was determined by the method of quadrats. The site had area of $0.01 \mathrm{~m}^{2}$; triple sampling with the sampling depth of 0-30 was performed. Vegetation tops were cut, dried and weighted. Monolith sample was studied in dry form with subsequent screening on 2-mm screens to remove residual soil. We also determined total air-dry weight of tops, afterharvest residues and roots. Then we recalculated units of harvested agrocoenosis (biocoenosis) biomass from $\mathrm{g} / \mathrm{dm}^{3}$ into $\mathrm{t} / \mathrm{ha}[4]$.

\section{EXPERIMENTAL RESULTS}

To determine the erosion level of slope soils, one needs comparing diagnostic indicators with those of benchmark species of soil taxons. We have made the cross section on the territory with most pronounced typical soil formation factors and on a flat relief with minimal slope as typical and leached chernozem benchmark samples. Moreover, by using the results of soil monitoring in Chelyabinsk region [1], we have compared all obtained parameters with typical soils and their virgin analogues. To exclude the effect of human factor on the diagnosis results, the cross sections were on the sites of longterm ploughing soil usage and their virgin analogues; thus, the benchmark samples were represented by soil cross sections in virgin soil and ploughland.

The diagnostic indicators of soil erosion level based on humus condition are: 1) decrease in humic layer thickness of eroded soils as percentage of non-eroded soil (benchmark sample); 2) decrease in humus stock in the profile of eroded soil as percentage of non-eroded soil (benchmark sample) as per USSR oils classification [5, 6, 7].
A notable thing in the consideration of performed morphological description of the cross sections on the slopes of different facing in steppe and forest steppe zones is that erosion processes during intense use of chernozemic soils as ploughlands are manifested with different intensity.

For example, the steppe typical chernozem of northern facing was compared with benchmark species and demonstrated declined thickness of humic layers by $8 \mathrm{~cm}$, which is $28 \%$; while the color of plough and sub-plough layers changes from dark gray to brownish gray. According to the classification, such eroded slope soils demonstrate weak to moderate degree of biologically active layer outwash. The organic content also varies from the watershed top down to its bottom. In the middle, the humus stock decrease is from 23 to $30 \%$; such eroded soils are called mid-outwashed. The thickness of humic layers, color range and relative humic content for soils of bottom part of watersheds (slopes) appreciably increases even for benchmark soils.

TABLE I. IMPACT OF FACING AND LOCATION ALONG THE SLOPE OF CHERNOZEMIC ERODED SOILS ON BIOMASS ABUNDANCE, PHYSICOCHEMICAL AND AGROCHEMICAL PROPERTIES

\begin{tabular}{|c|c|c|c|c|c|c|c|}
\hline \multirow{2}{*}{ 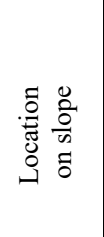 } & \multirow{2}{*}{ 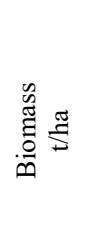 } & \multirow{2}{*}{ 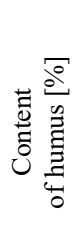 } & \multicolumn{2}{|c|}{$\begin{array}{c}\text { Granulometric } \\
\text { composition } \\
{[\%]}\end{array}$} & \multirow{2}{*}{ 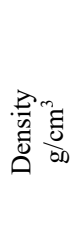 } & \multicolumn{2}{|c|}{$\begin{array}{l}\text { Agrochemical indi- } \\
\text { cators }\end{array}$} \\
\hline & & & $<0.01$ & $>0.01$ & & $\begin{array}{l}\mathrm{N}_{\text {total }} \\
{[\%]}\end{array}$ & $\begin{array}{l}\mathrm{P}_{\text {total }} \\
{[\%]}\end{array}$ \\
\hline \multicolumn{8}{|c|}{ Typical chernozem } \\
\hline \multicolumn{8}{|c|}{ Steppe soil erosion region, northern facing } \\
\hline $\begin{array}{l}\text { Top, } \\
\mathrm{n}=5\end{array}$ & 3.258 & 6.102 & 48.88 & 51.12 & 1.06 & 0.243 & 0.121 \\
\hline $\begin{array}{l}\text { Middle, } \\
\mathrm{n}=5\end{array}$ & 2.475 & 4.325 & 40.48 & 59.52 & 1.11 & 0.155 & 0.112 \\
\hline $\begin{array}{l}\text { Bottom } \\
n=5\end{array}$ & 2.638 & 5.805 & 54.70 & 45.30 & 1.11 & 0.219 & 0.134 \\
\hline $\mathrm{HCP}_{05}$ & 0.53 & 0.60 & \multicolumn{2}{|c|}{5.91} & 0.04 & 0.050 & 0.018 \\
\hline \multicolumn{8}{|c|}{ Steppe soil erosion region, southern facing } \\
\hline $\begin{array}{l}\text { Top, } \\
n=4\end{array}$ & 3.225 & 5.71 & 48.10 & 51.90 & 1.105 & 0.233 & 0.126 \\
\hline $\begin{array}{l}\text { Middle, } \\
\mathrm{n}=4\end{array}$ & 2.200 & 4.35 & 43.43 & 56.57 & 1.123 & 0.199 & 0.106 \\
\hline $\begin{array}{l}\text { Bottom } \\
n=4\end{array}$ & 3.195 & 6.11 & 53.60 & 46.40 & 1.133 & 0.218 & 0.123 \\
\hline $\mathrm{HCP}_{05}$ & 0.55 & 0.95 & \multicolumn{2}{|l|}{6.30} & $\mathrm{Ff}<\mathrm{Ft}$ & $\mathrm{Ff}<\mathrm{Ft}$ & $\mathrm{Ff}<\mathrm{Ft}$ \\
\hline \multicolumn{8}{|c|}{ Leached chernozem } \\
\hline \multicolumn{8}{|c|}{ Forest steppe soil erosion region, southern facing } \\
\hline $\begin{array}{l}\text { Top, } \\
\mathrm{n}=4\end{array}$ & 3.848 & 6.46 & 45.83 & 54.17 & 1.08 & 0.331 & 0.165 \\
\hline $\begin{array}{l}\text { Middle, } \\
\mathrm{n}=4\end{array}$ & 2.978 & 4.47 & 39.98 & 60.02 & 1.12 & 0.224 & 0.108 \\
\hline $\begin{array}{l}\text { Bottom } \\
n=4\end{array}$ & 3.880 & 6.43 & 43.98 & 56.02 & 1.10 & 0.284 & 0.147 \\
\hline $\mathrm{HCP}_{05}$ & 0.26 & 0.58 & \multicolumn{2}{|l|}{4.13} & 1.01 & 0.041 & 0.028 \\
\hline \multicolumn{8}{|c|}{ Forest steppe soil erosion region, northern facing } \\
\hline $\begin{array}{l}\text { Top, } \\
n=4\end{array}$ & 3.67 & 6.35 & 39.28 & 60.72 & 1.095 & 0.245 & 0.147 \\
\hline $\begin{array}{l}\text { Middle, } \\
n=3\end{array}$ & 2.91 & 4.61 & 31.50 & 68.50 & 1.130 & 0.137 & 0.098 \\
\hline $\begin{array}{l}\text { Bottom } \\
n=3\end{array}$ & 3.78 & 6.40 & 46.27 & 53.73 & 1.110 & 0.252 & 0.212 \\
\hline $\mathrm{HCP}_{05}$ & 0.61 & 0.92 & \multicolumn{2}{|l|}{3.28} & 0.027 & 0.041 & 0.023 \\
\hline
\end{tabular}


This testifies that the erosion process, flat outwashing in particular, facilitates the accumulation of matter in the bottom part of the slope. However, the alluvion is nonuniform, and the distribution of matter and energy reduces with increased distance from the slope bottom. The most contrasting manifestation of the processes described above is observed on the slopes of southern facing. Moreover, it is promoted by deflation, since a prominent part of slopes are located in windblowing position (dominance of southern and south-western winds) [8].

In the forest steppe zone, the contrast (degree) of manifested sheet water erosion is higher. This is evident from changing intensity of the color of humus accumulating layers from the slope top to its bottom. The color changes from dark gray to gray in the middle of the slope and dark gray with brownish hints in the bottom part of the slope. The losses of humic layer thickness on the slope for leached chernozem are significantly higher than that for typical steppe chernozem and reach $50 \%$. The losses of humus stock are also substantial and in relative units amount to $20-45 \%$ vs. benchmark values. Similarly to the steppe zone, in forest steppes, southern facing slopes are more susceptible to erosion, and in some cases the degree of outwash of eroded leached chernozem is highly-outwashed.

We believe, the gather of vegetation biomass on zones of eroded soils is a basic parameter that characterizes the impact of erosion level on the productivity of agrocoenosis. This is valid both in regard to main products, secondary products, afterharvest residues and roots, and in regard to the gather from zones of virgin soil and meadowed soil not used for farming over some period of time.

The biomass of eroded typical chernozem vegetation was confirmed to drop from the top boundary of the slope to the bottom. The losses from the slope of northern facing amounted to $24 \%, 0.783 \mathrm{t} / \mathrm{ha}$ for $\mathrm{HCP}_{05}=0.53 \mathrm{t} / \mathrm{ha}$; for southern facing they amounted to $32 \%, 1.025 \mathrm{t} / \mathrm{ha}$ for $\mathrm{HCP}_{05}=$ $0.55 \mathrm{t} / \mathrm{ha}$. In the bottom part of the slope, the outwashed substances accumulate, which promoted the fertility of biomass (Table 1).

For instance, on the slope of northern facing, the gather of biomass amounted to $2.638 \mathrm{t} / \mathrm{ha}$, which is $0.163 \mathrm{t} / \mathrm{ha}$ larger than that for the middle part of the slope. Though the surplus is within the limits of appreciable difference, we can speak about an increasing trend of this parameter. In relation to the top boundary of the slope, the decrease amounted to $0.62 \mathrm{t} / \mathrm{ha}$ for $\mathrm{HCP}_{05}=0.53 \mathrm{t} / \mathrm{ha}$, which is significant. On the slope of southern facing, the difference is more evident in regard to the middle section, while in the bottom part of the slope, the outwashed substance accumulated up to the level of the top boundary.

The content of humus adequately grows, the granulometric composition turns into heavy loams, which testifies increased capacity of cation exchange and total content of fertilizer macroelements.

Better conditions in terms of humidity provision to leached chernozem of forest steppe in comparison with steppe typical chernozem lead to more expressed change in fertility parameters of eroded forest steppe soil slopes from their top to the middle part and further to the bottom (Table 1).
The content of humus was confirmed to decrease from the slope middle part both from north and from south. On the northern facing of leached chernozem, its average content in the middle of the slope is lower by $1.99 \%$ at $\mathrm{HCP}_{05}=0.58 \%$; on the southern facing the situation is similar, the content is lower by $1.74 \%$ at $\mathrm{HCP}_{05}=0.92 \%$. This is accompanied by confirmed change in the biomass gather from top to middle part of the slope: for southern facing, the decrease is $0.87 \mathrm{t} / \mathrm{ha}$ at $\mathrm{HCP}=0.26 \mathrm{t} / \mathrm{ha}$, for northern facing, the decrease is $0.76 \mathrm{t} / \mathrm{ha}$ at $\mathrm{HCP}_{05}=0.61 \mathrm{t} / \mathrm{ha}$.

The granulometric composition of soil in slope top part is moderately loamy, in the middle it is lightly loamy, while in the bottom part it is heavily loamy. The changes to the granulometric composition are explained by the outwash by water and sweeping by wind of tiny particles down the slope where they accumulate.

Soil bulk density depends on the packaging of soil particles, granulometric composition and content of organic substance.

Studied typical steppe and leached forest steppe chernozems after spring treatment have propitious bulk density $\left(1.03-1.10 \mathrm{~g} / \mathrm{cm}^{3}\right)$ in the plouging layer along the whole slope. However, in the sub-plough layer, the density abruptly rises $\left(1.46-1.16 \mathrm{~g} / \mathrm{cm}^{3}\right)$, which is a result of constant soil treatment at similar depth.

The humus content also affected the density of the subplough layer. For instance, in the middle part of the slope at reduced humus content $(4 \%)$, the density amounted to $1.14 \mathrm{~g} / \mathrm{cm}^{3}$, while in the bottom and top part of the slope at high humus content, the soil density is lower, $1.06 \mathrm{~g} / \mathrm{cm}^{3}$ and $1.09 \mathrm{~g} / \mathrm{cm}^{3}$.

The increase in the density in the middle part of the slope is explained by simpler granulometric composition due to fine earth outwash on both south and north facing slopes.

In lower layers, the bulk density increases correspondingly to the decrease in content of organic matter and amounts to $1.45-1.51 \mathrm{~g} / \mathrm{cm}^{3}$.

To determine the threshold values of indicators affecting the gather of vegetation biomass, we have made a regression analysis of relationship strength of the changes to the parameter and properties of eroded chernozemic soils.

In a steppe eroded soil region where the soils are presented by eroded typical chernozems of both southern and northern facing, there is a strong to moderate relationship strength between biomass with humus content and total content of fertilizer elements, primarily with phosphorus and nitrogen.

The relationship is linear and described by the following equations:

$$
\begin{aligned}
& \text { Northern facing }-\mathrm{BM}=0.3653 \mathrm{H}+0.83(1) \\
& \text { Southern facing }-\mathrm{BM}=0.6928 \mathrm{H}+0.86(2) \\
& \text { where } \mathrm{BM} \text { is biomass gather in } \mathrm{t} / \mathrm{ha} \text {; }
\end{aligned}
$$

$\mathrm{H}$ is humus content in $\%$.

In the forest steppe, the relationship strength between the biomass gather and eroded leached chernozem properties is also strong in regard to humus content and fertilizer elements. In terms of other parameters characterizing the soil fertility, the relationship strength is not stable, though it is more contrasting as compared to the conditions of steppe landscape. 
From our perspective it is explained by more humid conditions of chernozemic soils formation and more complex granulometric composition of the solid phase.

The dependence of biomass on humus content is also described by the following linear equations:

$$
\begin{aligned}
& \text { Northern facing }-\mathrm{BM}=0.3615 \mathrm{H}+1.3382 \text { (3) } \\
& \text { Southern facing }-\mathrm{BM}=0.4383 \mathrm{H}+1.0244 \text { (4) } \\
& \text { where } \mathrm{BM} \text { is biomass gather in } \mathrm{t} / \mathrm{ha} \text {; }
\end{aligned}
$$

$\mathrm{H}$ is humus content in $\%$.

Under the conditions of forest steppe natural climatic zone, we have obtained strong and moderate relationship strength between total content of fertilizer elements. The dependence is linear and the regression equations are as follows:

For total nitrogen content:

$$
\text { Northern facing }-\mathrm{BM}=7.1442 \mathrm{~N}_{\text {total }}+1.9429 \text { (5) }
$$$$
\text { Southern facing }-\mathrm{BM}=7.9006 \mathrm{~N}_{\text {total }}+1.3601 \text { (6) }
$$

where $\mathrm{BM}$ is biomass gather in $\mathrm{t} / \mathrm{ha}$;

$\mathrm{N}_{\text {total }}$ is nitrogen content in \%;

For total phosphorus content:

Northern facing $-\mathrm{BM}=7.9588 \mathrm{P}_{\text {total }}+2.2577$ (7)

Southern facing $-\mathrm{BM}=12.877 \mathrm{P}_{\text {total }}+1.7597$ (8)

where $\mathrm{BM}$ is biomass gather in $\mathrm{t} / \mathrm{ha}$;

$\mathrm{P}_{\text {total }}$ is phosphorus content in $\%$.

The confidence factor of received results (Student coefficient) testifies the validity of the calculations.

By using the relationship strength of biomass with humus content, fertilizer elements and derived regression equations, we have calculated the threshold values of the scale of eroded chernozemic ploughland under various conditions of slope facing and territory of soil and climatic zone.

Calculation of threshold values of humus content.

Typical chernozem of northern facing, steppe zone:

The regression equations are as follows:

$\mathrm{BM}=0.37 \mathrm{H}+0.83(9) ; \mathrm{BM}=6.93 \mathrm{~N}_{\text {total }}+1.35(10)$;

$\mathrm{BM}=13.16 \mathrm{P}_{\text {total }}+1.14$ (11)

where $\mathrm{BM}$ is biomass gather in $\mathrm{t} / \mathrm{ha}$;

$\mathrm{H}$ is humus content in $\%$.

$\mathrm{N}_{\text {total }}$ is nitrogen content in \%;

$\mathrm{P}_{\text {total }}$ is phosphorus content in $\%$.

The calculation equation takes the following form:

$\mathrm{H}=\left(\left(\left(6.93 \mathrm{~N}_{\text {total }}+1.35+13.16 \mathrm{P}_{\text {total }}+1.14\right) / 2\right)-0.83\right) / 0.37(12)$;

Assuming the critical content of total nitrogen and total phosphorus of $0.05 \%$, we can solve the equation and obtain the minimum threshold of humus content $\mathrm{H}=2.48 \%$.

At minimum content of fertilizer elements, total nitrogen and total phosphorus of $0.1 \%$ we get the upper value of unacceptable level. The content of humus in this case will be $\mathrm{H}=3.84 \%$.
Typical chernozem of southern facing, steppe zone:

The regression equations are as follows:

$\mathrm{BM}=0.69 \mathrm{H}-0.86$ (13); $\mathrm{BM}=10.91 \mathrm{~N}_{\text {total }}+0.51$ (14);

$\mathrm{BM}=39.18 \mathrm{P}_{\text {total }}-1.82$ (15)

where $\mathrm{BM}$ is biomass gather in $\mathrm{t} / \mathrm{ha}$;

$\mathrm{H}$ is humus content in $\%$.

$\mathrm{N}_{\text {total }}$ is nitrogen content in \%;

$\mathrm{P}_{\text {total }}$ is phosphorus content in \%.

The calculation equation takes the following form:

$\mathrm{H}=\left(\left(\left(10.91 \mathrm{~N}_{\text {total }}+0.51+39.18 \mathrm{P}_{\text {total }}-1.82\right) / 2\right)+0.86\right) / 0.69$ (16);

Assuming the critical content of total nitrogen and total phosphorus of $0.05 \%$, we can solve the equation and obtain the minimum threshold of humus content $\mathrm{H}=2.11 \%$.

At minimum content of fertilizer elements, total nitrogen and total phosphorus of $0.1 \%$ we get the upper value of unacceptable level. The content of humus in this case will be $\mathrm{H}=3.93 \%$.

\begin{tabular}{|c|c|c|c|c|c|c|}
\hline \multirow{2}{*}{$\begin{array}{l}\text { Parameters } \\
\text { of regression }\end{array}$} & \multirow{2}{*}{ 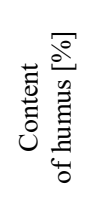 } & \multicolumn{2}{|c|}{$\begin{array}{c}\text { Granulometric } \\
\text { composition } \\
{[\%]}\end{array}$} & \multirow{2}{*}{ 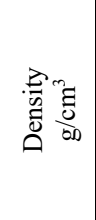 } & \multicolumn{2}{|c|}{$\begin{array}{l}\text { Agrochemical in- } \\
\text { dicators }\end{array}$} \\
\hline & & $<0.01$ & $>0.01$ & & $\begin{array}{l}\mathrm{N}_{\text {total }} \\
{[\%]}\end{array}$ & $\begin{array}{c}\mathrm{P}_{2} \mathrm{O}_{5} \\
\text { total } \\
{[\%]}\end{array}$ \\
\hline \multicolumn{7}{|c|}{ Steppe soil erosion region } \\
\hline \multicolumn{7}{|l|}{ northern facing } \\
\hline $\begin{array}{l}\text { Correlation } \\
\text { coefficient (r) }\end{array}$ & 0.623 & 0.240 & 0.240 & -0.560 & 0.640 & 0.450 \\
\hline $\begin{array}{l}\text { Relationship } \\
\text { strength }\end{array}$ & $\begin{array}{l}\text { mod- } \\
\text { erate }\end{array}$ & weak & weak & weak & $\begin{array}{l}\text { mod- } \\
\text { erate }\end{array}$ & weak \\
\hline \multicolumn{7}{|l|}{ southern facing } \\
\hline $\begin{array}{l}\text { Correlation } \\
\text { coefficient (r) }\end{array}$ & 0.776 & 0.196 & 0.196 & 0.337 & 0.283 & 0.717 \\
\hline $\begin{array}{l}\text { Relationship } \\
\text { strength }\end{array}$ & strong & weak & weak & weak & weak & strong \\
\hline \multicolumn{7}{|c|}{ Forest steppe soil erosion region } \\
\hline \multicolumn{7}{|c|}{ northern facing } \\
\hline $\begin{array}{l}\text { Correlation } \\
\text { coefficient (r) }\end{array}$ & 0.926 & 0.738 & 0.738 & -0.321 & 0.847 & 0.854 \\
\hline $\begin{array}{l}\text { Relationship } \\
\text { strength }\end{array}$ & strong & strong & weak & strong & strong & strong \\
\hline \multicolumn{7}{|l|}{ southern facing } \\
\hline $\begin{array}{l}\text { Correlation } \\
\text { coefficient (r) }\end{array}$ & 0.926 & 0.738 & 0.738 & 0.321 & 0.847 & 0.854 \\
\hline $\begin{array}{l}\text { Relationship } \\
\text { strength }\end{array}$ & strong & strong & weak & strong & strong & strong \\
\hline
\end{tabular}

TABLE II. REGRESSION ANALYSIS OF RELATION OF BIOMASS GATHER, PHYSICOCHEMICAL AND AGROCHEMICAL PARAMETERS OF CHERNOZEMIC SOILS

Leached chernozem of northern facing, steppe zone:

The regression equations are as follows:

$\mathrm{BM}=0.36 \mathrm{H}+1.34(17) ; \mathrm{BM}=7.14 \mathrm{~N}_{\text {total }}+1.94$ (18);

$\mathrm{BM}=7.96 \mathrm{P}_{\text {total }}+2.26$ (19)

where $\mathrm{BM}$ is biomass gather in $\mathrm{t} / \mathrm{ha}$;

$\mathrm{H}$ is humus content in $\%$.

$\mathrm{N}_{\text {total }}$ is nitrogen content in $\%$; 
$\mathrm{P}_{\text {total }}$ is phosphorus content in \%.

The calculation equation takes the following form:

$\mathrm{H}=\left(\left(\left(7.14 \mathrm{~N}_{\text {total }}+1.94+7.96 \mathrm{P}_{\text {total }}+2.26\right) / 2\right)-1.34\right) / 0.36(20)$;

Assuming the critical content of total nitrogen and total phosphorus of $0.05 \%$, we can solve the equation and obtain the minimum threshold of humus content $\mathrm{H}=3.16 \%$.

At minimum content of fertilizer elements, total nitrogen and total phosphorus of $0.1 \%$ we get the upper value of unacceptable level. The content of humus in this case will be $\mathrm{H}=4.20 \%$.

Leached chernozem of southern facing, steppe zone:

The regression equations are as follows:

$\mathrm{BM}=0.44 \mathrm{H}+1.02(21) ; \mathrm{BM}=7.90 \mathrm{~N}_{\text {total }}+1.36(22)$;

$\mathrm{BM}=12.88 \mathrm{P}_{\text {total }}+1.76(23)$

where $\mathrm{BM}$ is biomass gather in $\mathrm{t} / \mathrm{ha}$;

$\mathrm{H}$ is humus content in $\%$.

$\mathrm{N}_{\text {total }}$ is nitrogen content in $\%$;

$\mathrm{P}_{\text {total }}$ is phosphorus content in \%.

The calculation equation takes the following form:

$\mathrm{H}=\left(\left(\left(7.90 \mathrm{~N}_{\text {total }}+1.36+12.88 \mathrm{P}_{\text {total }}+1.76\right) / 2\right)-1.02\right) / 0.44(12)$;

Assuming the critical content of total nitrogen and total phosphorus of $0.05 \%$, we can solve the equation and obtain the minimum threshold of humus content $\mathrm{H}=2.41 \%$.

At minimum content of fertilizer elements, total nitrogen and total phosphorus of $0.1 \%$ we get the upper value of unacceptable level. The content of humus in this case will be $\mathrm{H}=3.59 \%$.

The calculations were used as the basis for the grading scale of eroded chernozemic ploughland (Table 3 ). In the last column of the table, eroded soils are given that are classified into different groups in terms of erosion level.

TABLE III. GRADING SCALE OF ERODED CHERNOZEMIC PLOUGHLAND

\begin{tabular}{|c|c|c|c|}
\hline $\begin{array}{l}\text { Level of } \\
\text { erosion }\end{array}$ & $\begin{array}{l}\text { Soil erosion } \\
\text { region }\end{array}$ & $\begin{array}{l}\text { Facing of } \\
\text { slope }\end{array}$ & $\begin{array}{c}\text { Content of } \\
\text { humus in layer } \\
0-25[\%]\end{array}$ \\
\hline \multirow{4}{*}{ Acceptable } & \multirow{2}{*}{ Steppe } & Northern & $3.85-5.50$ \\
\hline & & Southern & $3.94-5.50$ \\
\hline & \multirow{2}{*}{ Forest steppe } & Northern & $4.21-6.50$ \\
\hline & & Southern & $3.60-6.50$ \\
\hline \multirow{4}{*}{ Unacceptable } & \multirow{2}{*}{ Steppe } & Northern & $2.49-3.84$ \\
\hline & & Southern & $2.11-3.93$ \\
\hline & \multirow{2}{*}{ Forest steppe } & Northern & $3.17-4.20$ \\
\hline & & Southern & $2.42-3.59$ \\
\hline \multirow{4}{*}{ Critical } & \multirow{2}{*}{ Steppe } & Northern & 2.48 and less \\
\hline & & Southern & 2.10 and less \\
\hline & \multirow{2}{*}{ Forest steppe } & Northern & 3.16 and less \\
\hline & & Southern & 2.41 and less \\
\hline
\end{tabular}

\section{DISCUSSION}

The studies have shown that the Southern Urals has colossal soil and climatic resources, as well as organizational and economical capabilities and can take rightful place in Russia and the world in farming industry, including plant growing. Even within Chelyabinsk region one can note that agrobiocenoses over 40-45 years have appreciably decreased their productivity. In the majority of cases, it was conditioned by negligent attitude of land users towards rehabilitation of soil fertility. After the efficacy of state programs for support of agriculture producers dropped due to different reasons, the deterioration of soil resources on the territory of the Southern Urals increased, including wind and water erosion on appreciable areas. Even those territories that over long time were considered successful in terms of considered indicators have suffered the negative effect of sheet and even linear outwash of biologically active, i.e. the most productive, soil layers.

The study and analysis of morphological markers of chernozemic soils erosion degree have determined that (according to USSR soil classification of 1977 [5]) typical chernozem on slopes from 3 to 4 degrees of both southern and northern facing features weak to moderate removal of humic layers; leached chernozem features weak to strong removal. Water erosion is more pronounced on slopes of southern facing.

To determine the impact of erosion on the alteration of the properties of chernozemic soils on slopes, physicochemical and agrochemical parameters were determined, regression analysis of the relationship strength of soil fertility parameter with vegetation biomass was carried out. The data obtained allowed identifying the largest relationship of the change to vegetation biomass with such fertility parameters as presence of humus (organic matter), total content of nitrogen and phosphorus, granulometric composition. The most contrasting manifestation of this is observed on the slopes of southern facing and in forest steppe.

We believe that the the approach to diagnosis of soil erosion suggested by V.I. Kiryushin and N.A. Ganzhara absolutely meets modern requirements. This approach was approved by the Soil research institute named after Dokuchaev. The authors have introduced the terms acceptable, unacceptable and critical level of organic matter content (humus) [9].

\section{CONCLUSION}

Using the results of regression analysis and data on minimal and critical content of humus in chernozemic soils of the Southern Urals, we have calculated the grading scale for the erosion degree of eroded soils that allows determining the erosion degree with minimum costs and decide on the necessity of activities stopping the erosion and enhancing soil fertility.

At acceptable level of erosion, current farming system satisfies zoning soil protection technologies; however, they require adaptation to natural, economic and ecological conditions.

Unacceptable level of erosion envisages the following measures classified into groups:

Organizational measures include:

- survey of land and formation of electronic database with identification of soil categories in terms of erosion degree, usage character, contours with uniform agroecological conditions, etc.;

- development of the system for crop rotation and contourbased structure of cultivation areas meeting the requirements to soil erosion protection;

- correction of soil protection technologies for cultivation of certain crops;

- development of all elements of farming soil protection with due consideration of specific ecological conditions 
(slope facing, micro-relief, zonal belonging of the territory, water regime, etc.).

Agrotechnical measures:

- meeting the requirements of soil protection technologies (special equipment and tools, soil treatment, selection of crops, the fraction of perennial grasses not less than $15-20 \%$ in the structure of cultivation areas, fraction of complete fallow, etc.);

- development of fertilizer systems has compensation character with obligatory application of organic fertilizers with primary introduction of mineral fertilizers.

Social and economic measures:

- issues on organization of land usage are solved in regard to specific farming enterprise with due consideration of its profiles and development prospects by concluding separate two-side commercial contracts;

- state subsidies to compensate expenditures for rehabilitation of eroded soil fertility, regional co-funding programs or compensation of expenditures.

At critical erosion level, the rehabilitation of the agroecosystem of chernozemic soils should be made in two stages.

The first step is remediation of natural soil forming process. The primary measure is meadow amelioration with limitation of the territory usage for farming. Restoration of natural grass stand is made according to the principle of radical amelioration.

The elimination of old organic mat (hayfields and pastures) or crop residues on a ploughland should be carried out as bands across the slope. The bands should alternate in time and space.

To prevent the outwash at the first stages of growth and development of perennial vegetation, paraploughing or moling should be performed using adequate tools.

To improve the feeding schedule and activation of microbiological activities, organic fertilizers are introduced in an amount of 30-35 t/ha of semi-decomposed manure that can be replaced by other types of local fertilizers (decomposed poultry manure, sapropel, etc.) with corresponding correction of introduced amount.
The preparation of a field for seeding includes leveling of the surface by several alternating in depth treatments, from deep blade cultivation to harrowing by light harrows in spring before grass seeding.

In the case of appreciable areas of contours of damaged soils, forest amelioration is used. Composition of forest bands, their location in relation to the slope and distance between them are calculated individually for conditions and territories of each case.

The second stage is implementation of the system of adaptive landscape farming on contour basis; the measures are the same as for the scheme proposed in the case of unaccepted erosion level.

\section{References}

[1] A. P. Kozachenko, Justification of methods of rational use, processing and reclamation of agricultural land in the Chelyabinsk region, Chelyabinsk: Chau, 1999.

[2] G. T. Balakay, E. V. Poluektov, et al., Guidelines for the purpose of compensatory ameliorative measures to reduce surface runoff from agricultural land, FGB WELL "Rosnipi", Novocherkassk, 2015.

[3] Guidelines for the protection of soil from water erosion and deflation in the Chelyabinsk region, South Ural niiz, Chelyabinsk, 1981.

[4] V. V. Kidin, Workshop on agricultural chemistry, Moscow: Colossus, 2008.

[5] Classification and diagnosis of soils of the USSR, Moscow: Kolos, 1977.

[6] V. A. Rozhkov, Evaluation of soil erosion hazard, bul. Soils'. in-TA im. V. V. Dokuchaeva. 2007, no. 59, pp. 77-91.

[7] Surikova V. I. Diagnosis and classification of eroded soils // Eroded soils and the effectiveness of soil conservation measures: Scientific. Tr. Soils'. in-TA im. V. V. Dokuchaeva, 1987, pp. 88-96.

[8] I. V. Sinyavsky, Effect of the degree of erosion on the morphological characteristics of Chernozem soils of the southern Urals, Proc. of International scientific-practical conference PROBLEMS of the Agricultural Sector of the South Urals and Ways for Their Solution of the Institute of Agroecology, 2018, pp. 140-148.

[9] B. M. Kogut, Evaluation of levels of erosion of the topsoil relative to their degree of humus content, Bulletin of Soil Institute. V. V. Dokuchaeva, 2015, no. 78, pp. 59-69. 